\title{
TAPER MODELING AND ECONOMIC EVALUATION OF MULTI- PRODUCTS OBTAINED FROM WOOD OF SHORT-ROTATION EUCALYPTUS STANDS
}

\author{
Luciana da Silva Menezes ${ }^{1}$, Joice Beatriz Lopes Figueiredo ${ }^{1}$, Lidiomar Soares da Costa ${ }^{2 *}$, Renato Vinícius \\ Oliveira Castro ${ }^{1}$, Carlos Alberto Araújo Júnior ${ }^{3}$. \\ ${ }^{1}$ Universidade Federal de São João del Rey, Departamento de Ciências Agrárias, Campus Sete Lagoas, Sete Lagoas, Minas Gerais, Brasil - \\ ateluciana@gmail.com; joicebeatriz16@hotmail.com; castrorvo@ymail.com \\ ${ }^{2 *}$ Universidade Federal de Uberlândia, Instituto de Ciências Agrárias, Campus Monte Carmelo, Monte Carmelo, Minas Gerais, Brasil - \\ lidiomar.ef@gmail.com \\ ${ }^{3}$ Universidade Federal de Minas Gerais, Instituto de Ciências Agrárias, Campus Montes Claros, Montes Claros, Minas Gerais, Brasil - \\ araujocaj@gmail.com
}

Received for publication: 14/07/2018 - Accepted for publication: 23/04/2020

\begin{abstract}
Resumo
Modelagem do afilamento e avaliação econômica de multiprodutos da madeira de povoamentos de eucalipto em curta rotação. Este estudo foi desenvolvido com o objetivo de definir o modelo adequado para descrever o afilamento de árvores do híbrido de Eucalyptus urophylla x Eucalyptus grandis, além de avaliar a viabilidade econômica da produção de multiprodutos a diferentes taxas de juros. Foram cubadas 60 árvores-amostra e o afilamento dos fustes descritos pelos modelos de Demaerschalk, Prodan, Kozak e Ormerod. O melhor modelo foi utilizado para converter as árvores em sortimentos de forma ótima e então realizou-se a análise de viabilidade econômica para multiprodutos da madeira, por meio do Valor Presente Líquido, aplicando-se taxas de juros de 8 a $12 \%$ a.a.. O modelo de Demaerschalk é o mais adequado para o estudo de afilamento do fuste e determinação dos sortimentos em povoamento de híbrido de Eucalyptus urophylla x Eucalyptus grandis destinado a multiprodutos em povoamento de ciclo curto para a região de abrangência do estudo. A destinação da madeira para multiprodutos é opção viável para povoamentos do híbrido Eucalyptus urophylla x Eucalyptus grandis segundo as taxas de juros aplicadas no presente estudo.

Palavras-chave: Projetos florestais; otimização florestal; retorno econômico
\end{abstract}

\begin{abstract}
This study aims at defining the appropriate model to describe the stem tapering of trees of Eucalyptus urophylla $\mathrm{x}$ Eucalyptus grandis hybrid, and at evaluating the economic viability of obtaining wood multi-products at different interest rates. The volume of 60 sample trees were determined, and stem tapering was described according to the models proposed by Demaerschalk, Prodan, Kozak, and Ormerod. The best model was used to convert the trees into assortments so that the wood could be optimized for the product that offers the maximum economic return with the minimum possible waste. Then, an economic viability analysis was performed for wood multi-product production, using the Net Present Value (NPV) and applying interest rates of 8 to $12 \%$ p.a. The Demaerschalk model is the most appropriate one for the study of stem tapering and assortment determination in short-rotation stands of the Eucalyptus urophylla $\mathrm{x}$ Eucalyptus grandis hybrid intended for multi-products in the region covered by the study. The allocation of wood for multi-products is a viable option for stands of the Eucalyptus urophylla $\mathrm{x}$ Eucalyptus grandis hybrid, according to the interest rates applied in the present study.

Keywords: Forestry projects; forest optimization; economic return.
\end{abstract}

\section{INTRODUCTION}

The use of forest stands to obtain wood multi-products has long been sought. In such practice, from the same stem of a tree it is possible to allocate wood for different uses, and forests could guarantee maximum economic return and better wood use. It is known that to use multi-products of the tree, it is necessary to obtain precise data on volume and pre-defined commercial diameters. However, the various shapes of the stem profile depending on the species and its stage of development hinder the estimation of this diameter.

One of the profile variations is tapering, which consists in the natural decrease in diameter along the stem and has a direct effect on the volume of the trees. This knowledge is crucial in forest inventories for wood multiproducts, and a mathematical model that describes tapering must be defined, thus determining the volume of wood between any points along the stem (YOSHITANI JÚNIOR et al., 2012; HUSCH et al., 2017).

Therefore, taper functions are an excellent option to quantify the multiple products of the wood from forest stands. Moreover, the large amount of information they generate has conducted to the development of

FLORESTA, Curitiba, PR, v. 50, n. 3, p. 1439 - 1448, jul/set 2020

Menezes, L.S. et.al.

ISSN eletrônico 1982-4688

DOI: $10.5380 /$ rf.v50 i3. 60513 
different techniques for modeling the stem profile of forest species (SILVA et al., 2011; LEITE et al., 2011; LANSSANOVA et al., 2013; MÜLLER et al., 2014). Several regression models have already been proposed and employed to describe stem tapering, such as Prodan (1965), Demaerschalk (1972), Kozak (1969), and Ormerod (1973) (CAMPOS; LEITE, 2017).

Evaluating models to describe the diameter growth in different situations and knowing the multiplicity of forest products available from Eucalyptus stands enable the forest manager to direct the activities towards the supply of multi-products obtained from log conversion. Such procedure represents a competitive differential, as it adds increasing flexibility with regards to the commercialization of products, reducing the risks of losses (SOARES et al., 2003).

In recent years, studies have been performed in Brazil regarding the economic evaluation of Eucalyptus stands for wood multi-products, however, these studies have considered thinning in forest stands and higher rotation ages (VITALE; MIRANDA, 2010; CASTRO et al., 2011). However, further studies are necessary to demonstrate the possibility of producing wood multi-products from short-rotation forests (6 to 7 years) with no application of thinning or other silvicultural techniques in addition to those normally applied in forests allocated for a single use of wood, even in smaller proportions.

Therefore, the present study aimed at determining the best model to describe the stem tapering of trees of Eucalyptus urophylla x Eucalyptus grandis hybrid, applying this model in a log cutting optimization system in wood multi-products, and evaluating the use of forest stands to obtain multi-products at different interest rates using an economic analysis.

\section{MATERIAL AND METHODS}

The data used in this study were obtained from a stand of Eucalyptus urophylla $\mathrm{x}$ Eucalyptus grandis hybrid established at an initial spacing of $3.0 \mathrm{~m}$ x $2.5 \mathrm{~m}$, located in the city of Martinho Campos (state of Minas Gerais, Brazil). The climate of the region is CWA type, according to the Köppen classification, and is characterized by humid summers and dry winters, with an average annual temperature between 19.8 and $25.3^{\circ} \mathrm{C}$ and average annual precipitation of $1400 \mathrm{~mm}$ (SILVA et al., 2012).

Dendrometric data were collected at the harvest age (6.5 years) through a forest inventory, and 33 rectangular plots measuring $256 \mathrm{~m}^{2}$ were sampled. In each plot, trees with a diameter at breast height (DBH) greater than or equal to $5.0 \mathrm{~cm}$ had their respective $\mathrm{DBH}$ and total height measured. In order to generate volume and taper equations, sixty sample trees were felled and measured. They represented all diameter classes observed in the stand. The measurements for diameter and bark thickness were performed in the following stem positions: base, $0.5 \mathrm{~m}, 1.0 \mathrm{~m}, 1.3 \mathrm{~m}, 2.0 \mathrm{~m}$, and from that height on every $2.0 \mathrm{~m}$ up to a minimum commercial diameter of $3.0 \mathrm{~cm}$. The volume of each section was obtained using the Smalian formula.

In order to describe the stem tapering, the following taper models were compared: Demaerschalk (1972), Kozak (1969), Ormerod (1973), and Prodan (1965) (equations 1 to 4), as presented hereinafter.

a) DEMAERSCHALK (1972)

$$
Y^{2}=10^{2 \beta_{0}} D A P^{2 \beta_{1}-2}(H t-h)^{2 \beta_{2}} \mathrm{Ht}^{2 \beta_{3}} \varepsilon
$$

b) KOZAK (1969)

$$
Y^{2}=\beta_{0}+\beta_{1}\left(\frac{h}{H}\right)+\beta_{2}\left(\frac{h}{H}\right)^{2}+\varepsilon
$$

c) ORMEROD (1973)

$$
Y^{2}=\left[\frac{H-h}{H-1,30}\right]^{2 \beta_{1}}+\varepsilon
$$

d) PRODAN (1965)

$$
Y=\beta_{0}+\beta_{1}\left(\frac{h}{H}\right)+\beta_{2}\left(\frac{h}{H}\right)^{2}+\beta_{3}\left(\frac{h}{H}\right)^{3}+\beta_{4}\left(\frac{h}{H}\right)^{4}+\beta_{5}\left(\frac{h}{H}\right)^{5}+\varepsilon
$$


Where: $Y: d / D B H ; h$ : height in any part of the tree; $H$ : tree total height; $d$ : diameter at height $h ; D B H$ : diameter of the tree at $1.3 \mathrm{~m}$ from the ground; $\beta_{0}, \beta_{1}, \beta_{2}, \beta_{3}, \beta_{4}$, and $\beta_{5}$ : regression parameters; $\varepsilon$ : random error.

The most appropriate model for the study was chosen based on the following statistics: mean absolute differences (MAD), correlation coefficient between observed values and estimated values of the dependent variable $\left(r_{\hat{Y}, Y}\right)$, root mean square error (RMSE), bias (\%) (equations 5 to 8), and residual plot analysis:

$$
\begin{aligned}
& M A D=\sum_{i=1}^{n} \frac{\left|Y_{i}-\hat{Y}_{i}\right|}{n} \\
& r_{\hat{Y}, Y}=\frac{\widehat{\operatorname{Cov}}(\hat{Y}, Y)}{\sqrt{V(\hat{Y}) V(Y)}} \\
& R M S E=\sqrt{\frac{\sum_{i=1}^{n}\left(Y_{i}-\hat{Y}_{i}\right)^{2}}{n}} \\
& \text { bias }_{\%}=100 \frac{1}{n} \sum_{i=1}^{n}\left[\left(Y_{i}-\hat{Y}_{i}\right) / Y_{i}\right]
\end{aligned}
$$

Where: $Y i_{\mathrm{e}} \hat{Y} i$ : observed and estimated values of the variable under the analysis of the i-th tree; $n$ : number of cases.

The selected model was used to convert the trees into assortments so that the wood could be optimized in the most profitable product with the least possible waste. In addition to it, an economic evaluation for three assortments of wood use was conducted: solid pieces (poles and fence posts) and energy (firewood to be converted into charcoal). The data of each tree was processed in the SigmaE software using dynamic programming (LEITE et al., 1995). The software allows the user to define the wood use for products with certain dimensions, based on the costs for obtaining them and their respective commercial values (Tables 1 and 2), assuming the existence of a demand. The cost of the land factor was considered using the interest rate method over the land value, as it provides

\begin{tabular}{|c|c|c|c|}
\hline Year & Activity & Value* & Unit \\
\hline 0 & Preparing the planting area & 117.59 & $\mathrm{R} \$ . \mathrm{ha}^{-1}$ \\
\hline 0 & Forest implementation & 1081.64 & $\mathrm{R} \$ . \mathrm{ha}^{-1}$ \\
\hline Subtotal Year 0 & & 1199.23 & $\mathrm{R} \$ . \mathrm{ha}^{-1}$ \\
\hline 1 & Silvicultural treatments 1 & 456.37 & $\mathrm{R} \$ . \mathrm{ha}^{-1}$ \\
\hline 1 & Infrastructure & 32.00 & $\mathrm{R} \$ . \mathrm{ha}^{-1}$ \\
\hline Subtotal Year 1 & & 488.37 & $\mathrm{R} \$ . \mathrm{ha}^{-1}$ \\
\hline 2 & Silvicultural treatments 2 & 378.40 & $\mathrm{R} \$ . \mathrm{ha}^{-1}$ \\
\hline 2 & Infrastructure & 96.00 & R\$.ha ${ }^{-1}$ \\
\hline Subtotal Year 2 & & 474.4 & $\mathrm{R} \$ . \mathrm{ha}^{-1}$ \\
\hline 3 & Silvicultural treatments 3 & 110.59 & $\mathrm{R} \$ . \mathrm{ha}^{-1}$ \\
\hline 3 & Infrastructure & 96.00 & $\mathrm{R} \$ . \mathrm{ha}^{-1}$ \\
\hline Subtotal Year 3 & & 206.59 & $\mathrm{R} \$ . \mathrm{ha}^{-1}$ \\
\hline 4 & Silvicultural treatments 4 & 21.99 & $\mathrm{R} \$ . \mathrm{ha}^{-1}$ \\
\hline 4 & Infrastructure & 96.00 & $\mathrm{R} \$ . \mathrm{ha}^{-1}$ \\
\hline Subtotal Year 4 & & 117.99 & R\$.ha ${ }^{-1}$ \\
\hline 5 & Silvicultural treatments 5 & 21.99 & $\mathrm{R} \$ . \mathrm{ha}^{-1}$ \\
\hline
\end{tabular}
results that are more consistent with commercial values, according to Silva et al. (2008).

Table 1. Production costs of forestry activity in the evaluated stand.

Tabela 1. Custos de produção da atividade florestal no povoamento avaliado.

FLORESTA, Curitiba, PR, v. 50, n. 3, p. 1439 - 1448, jul/set 2020.

Menezes, L.S. et.al.

ISSN eletrônico 1982-4688

DOI: 10.5380/rf.v50 i3. 60513 


\begin{tabular}{|c|c|c|c|}
\hline 5 & Infrastructure & 96.00 & $\mathrm{R} \$ . \mathrm{ha}^{-1}$ \\
\hline Subtotal Year 5 & & 117.99 & $\mathrm{R} \$ . \mathrm{ha}^{-1}$ \\
\hline 6 & Silvicultural treatments 6 & 21.99 & $\mathrm{R} \$ . \mathrm{ha}^{-1}$ \\
\hline 6 & Infrastructure & 96.00 & $\mathrm{R} \$ . \mathrm{ha}^{-1}$ \\
\hline Subtotal Year 6 & & 117.99 & $\mathrm{R} \$ . \mathrm{ha}^{-1}$ \\
\hline 7 & Silvicultural treatments 7 & 21.99 & $\mathrm{R} \$ . \mathrm{ha}^{-1}$ \\
\hline 7 & Infrastructure & 96.00 & $\mathrm{R} \$ . \mathrm{ha}^{-1}$ \\
\hline Subtotal Year 7 & & 117.99 & $\mathrm{R} \$ . \mathrm{ha}^{-1}$ \\
\hline 1 to 7 & Administration & 90.00 & $\mathrm{R} \$ . \mathrm{ha}^{-1}$ \\
\hline 1 to 7 & General expenses & 30.00 & $\mathrm{R} \$ \cdot \mathrm{ha}^{-1}$ \\
\hline 1 to 7 & Land cost & 190.00 & $\mathrm{R} \$ . \mathrm{ha}^{-1}$ \\
\hline Subtotal Year 1 to 7 & & 310.00 & $\mathrm{R} \$ . \mathrm{ha}^{-1}$ \\
\hline 7 & Pre-harvest ant control & 36.32 & $\mathrm{R} \$ . \mathrm{ha}^{-1}$ \\
\hline 7 & Mixed pre-harvest mowing & 82.00 & $\mathrm{R} \$ . \mathrm{ha}^{-1}$ \\
\hline Subtotal Year 7 & & 118.32 & $\mathrm{R} \$ . \mathrm{ha}^{-1}$ \\
\hline & Harvest & 27.72 & $\mathrm{R} \$ . \mathrm{m}^{-3}$ \\
\hline
\end{tabular}

* Data provided by S\&D Florestal

In addition to the aforementioned costs of forestry activity, the costs to process wood products were considered to be $30 \%$ of the gross revenue.

Table 2. Specifications of each assortment obtained per tree: dimensions and sales prices per piece (poles and fence posts) and per cubic meter (energy).

Tabela 2. Especificações de cada sortimento obtido por árvore: dimensões e preços de venda por peça (mourões e postes) e por metro cúbico (energia).

\begin{tabular}{lccc}
\hline Assortment & Length $(\mathbf{c m})$ & Minimum small-end diameter $(\mathbf{c m})$ & Price $^{*}$ \\
\hline Pole & 800 & 15.0 & $40.0(\mathrm{R} \$ / \mathrm{UN})$ \\
Fence post & 220 & 7.0 & $4.8(\mathrm{R} \$ / \mathrm{UN})$ \\
Energy & 50 & 3.0 & $40.0\left(\mathrm{R} \$ / \mathrm{m}^{3}\right)$ \\
\hline
\end{tabular}

* No wood treatment in the case of poles and fence posts.

After defining the best model, the economic evaluation of the production was performed considering the wood for multiple uses - wood poles, fence posts, and firewood for charcoal. In order to evaluate the viability, the Net Present Value (NPV) method was used. It is defined according to Rezende and Oliveira (2013) as:

- NPV: the algebraic sum of the discounted values of the cash flow associated with it, i.e., it is the difference between the present value of revenues minus the present value of costs. The essential feature of the NPV method is the discount of all expected cash flows as a result of an investment decision. Its formula is given by:

$$
N P V=\sum_{j=0}^{n} R_{j}(1+i)^{-j}-\sum_{j=0}^{n} C_{j}(1+i)^{-j}
$$

A project is considered economically viable if the NPV values are positive, indicating that the revenues are greater than the costs. When comparing two or more projects, the one with the highest values by this criterion will be the most economically viable. In this study, the minimum rate of attractiveness considered was $8.0 \%$. In order to conduct a sensitivity analysis concerning discount rates, rates from 8 to $12 \%$ p.a. were applied. This variation is commonly observed in the forestry sector.

\section{RESULTS}

The following variables are presented in Table 3: frequency (trees.ha $\left.{ }^{-1}\right)$, mean total height $(\mathrm{m})$, and basal area $\left(\mathrm{m}^{-2} \cdot \mathrm{ha}^{-1}\right)$ by DBH class. For frequency and basal area, the highest values were observed in the DBH classes of 17.0 and $19.0 \mathrm{~cm}$, respectively.

FLORESTA, Curitiba, PR, v. 50, n. 3, p. 1439 - 1448, jul/set 2020.

Menezes, L.S. et.al.

ISSN eletrônico 1982-4688

DOI: 10.5380/rf.v50 i3. 60513 
Table 3. Characteristics of the Eucalyptus urophylla $\mathrm{x}$ E. grandis hybrid stands: frequency (trees.ha' ${ }^{-1}$ ), mean total height $(\mathrm{Ht}, \mathrm{m})$, and basal area $\left(\mathrm{G}, \mathrm{m}^{2} \cdot \mathrm{ha}^{-1}\right)$ in the DBH classes from 5.0 to $27.0 \mathrm{~cm}$.

Tabela 3. Características do povoamento de híbrido Eucalyptus urophylla x E. grandis: frequência (árvores.ha-1 ${ }^{-1}$, altura total média $(\mathrm{Ht}, \mathrm{m})$ e Área Basal $\left(\mathrm{G}, \mathrm{m}^{2} \cdot \mathrm{ha}^{-1}\right)$ nas classes de diâmetro de 5,0 a 27,0 cm.

\begin{tabular}{cccc}
\hline DBH class & Frequency $\left(\right.$ tree.ha- $\left.^{-\mathbf{1}}\right)$ & Ht $(\mathbf{m})$ & $\mathbf{G ~}_{\left(\mathbf{m}^{\mathbf{2}} \mathbf{. h a}\right.}^{\mathbf{- 1})}$ \\
\hline 5.0 & 7 & 8.40 & 0.01765 \\
7.0 & 14 & 11.25 & 0.06108 \\
9.0 & 65 & 14.76 & 0.43263 \\
11.0 & 127 & 17.90 & 1.21940 \\
13.0 & 169 & 20.78 & 2.22388 \\
15.0 & 198 & 23.42 & 3.51403 \\
17.0 & 248 & 25.46 & 5.63719 \\
19.0 & 214 & 27.15 & 5.98959 \\
21.0 & 59 & 28.95 & 1.99027 \\
23.0 & 14 & 29.78 & 0.57814 \\
27.0 & 2 & 31.72 & 0.12913 \\
\hline TOTAL & 1120 & - & 21.7930 \\
\hline
\end{tabular}

The taper models tested in this study presented significant parameters. Among those, the Demaerschalk model provided greater adjustment accuracy, which was demonstrated by the correlation coefficient between the observed and estimated values of the dependent variable $\left(r_{\hat{y} y}\right)$, RMSE, and bias $(\%)$. The Ormerod model, on the other hand, presented the highest MAD, the highest RMSE, bias greater than $30 \%$, and the lowest correlation between the observed and estimated diameters (Table 4).

Table 4. Parameters and statistics from the adjustment of the taper models of Demaerschalk (1972), Kozak (1969), Ormerod (1973) and Prodan (1965) for Eucalyptus urophylla x E. grandis hybrid.

Tabela 4. Parâmetros e estatísticas de ajuste dos modelos de afilamentos de Demaerschalk (1972), Kozak (1969), Ormerod (1973) e Prodan (1965) para híbrido de Eucalyptus urophylla x E. grandis.

\begin{tabular}{|c|c|c|c|c|c|c|c|c|c|c|}
\hline \multirow{2}{*}{ Models } & \multicolumn{6}{|c|}{ Parameters } & \multirow[b]{2}{*}{ MAD } & \multirow[b]{2}{*}{$r_{\hat{y} y}$} & \multirow[b]{2}{*}{ RMSE } & \multirow[b]{2}{*}{ Bias $(\%$} \\
\hline & $\boldsymbol{\beta}_{0}$ & $\beta_{1}$ & $\boldsymbol{\beta}_{2}$ & $\boldsymbol{\beta}_{3}$ & $\boldsymbol{\beta}_{4}$ & $\beta_{5}$ & & & & \\
\hline Demaerschalk & $0.13788^{*}$ & $1.01192^{*}$ & $0.55644^{*}$ & $-0.64715^{*}$ & - & - & 0.724 & 0.989 & 0.892 & 2.06 \\
\hline Kozak & $1.17764^{*}$ & $-1.59515^{*}$ & $0.49978^{*}$ & - & - & - & 0.803 & 0.984 & 1.093 & -4.49 \\
\hline Ormerod & - & $1.11277^{*}$ & - & - & - & - & 2.568 & 0.957 & 3.236 & 31.81 \\
\hline Prodan & $1.13643^{*}$ & $-2.51581^{*}$ & $10.32520^{*}$ & $-22.70564^{*}$ & $21.70677^{*}$ & $-7.71555^{*}$ & 0.684 & 0.985 & 0.993 & -2.80 \\
\hline
\end{tabular}

* $\mathrm{T}$ - test at a significance level of $5 \%$

The Demaerschalk model provided more homoscedastic results, showing little tendency to underestimate the diameters at the upper points of the stem. Prodan and Kozak models also demonstrated homoscedasticity but tended to underestimate and overestimate the lower diameters of the stem. The Ormerod model showed a strong tendency to underestimate the diameters at the lower and middle points of the tree (Figure 1). 

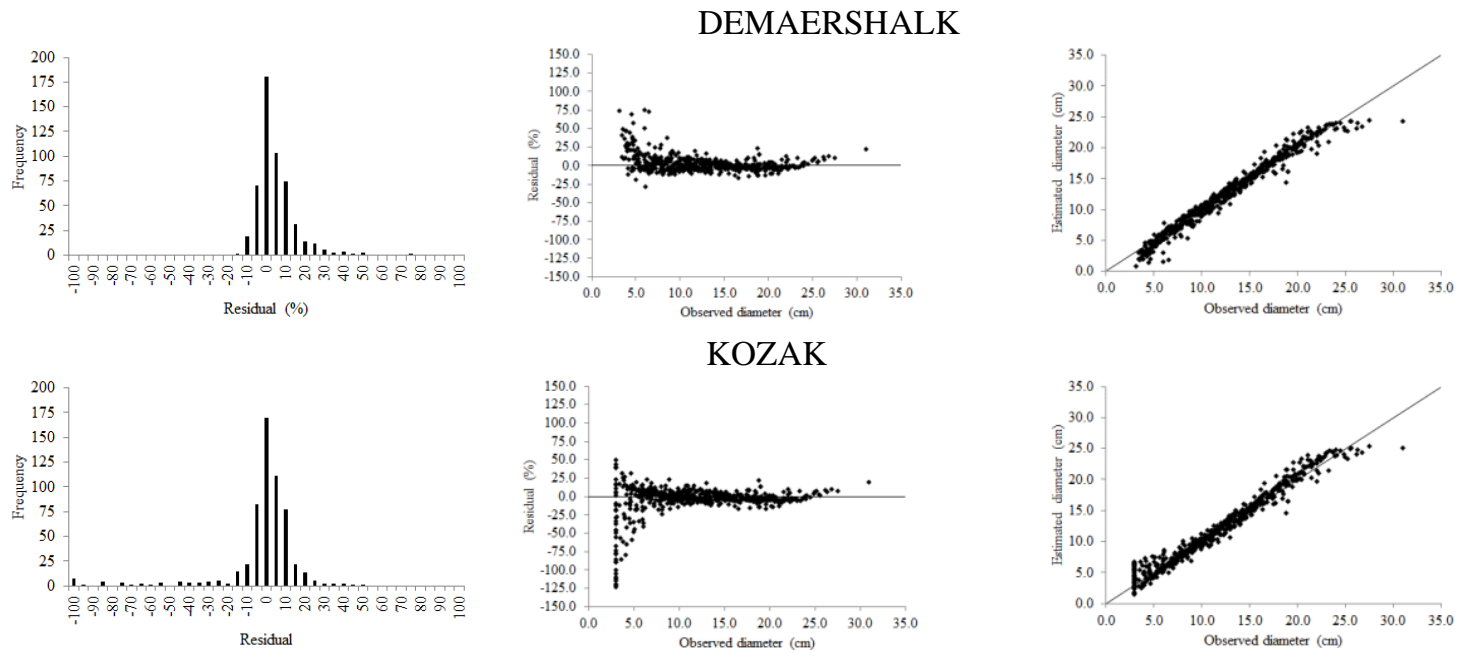

ORMEROD
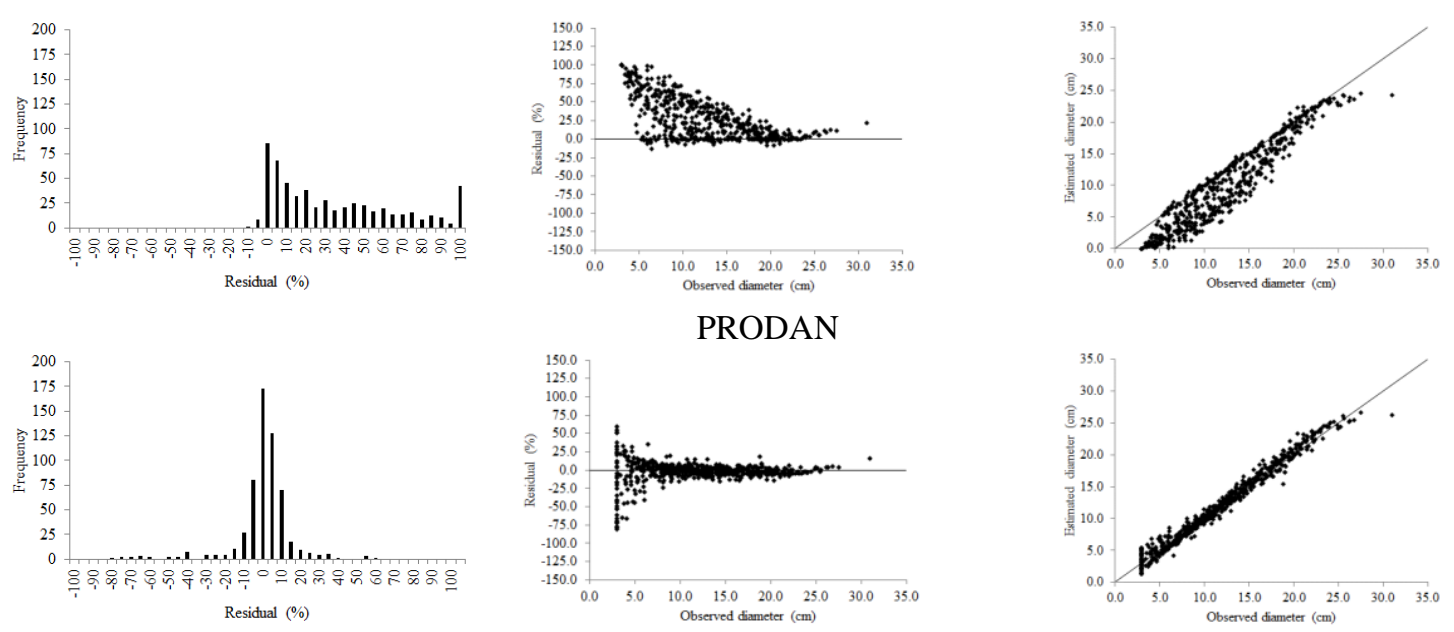

Figure 1. Residual plots, and comparison of the observed and estimated diameters at a given commercial height (h) for equations adjusted based on the following taper models: Demaerschalk (1972), Kozak (1969), Ormerod (1973), and Prodan (1965).

Figura 1. Distribuição gráfica de resíduos e comparação de diâmetro observado e estimado em determinada altura comercial (h) para equações ajustadas a partir dos modelos de afilamentos: Demaerschalk (1972), Kozak (1969), Ormerod (1973) e Prodan (1965).

In order to demonstrate the shape of the Eucalyptus urophylla $x$ E. grandis stem under the conditions of this study, an approximate representation of the profile of the trees was elaborated. It was based on the DBH class estimated by the Demaerschalk model (1972), through which it is possible to estimate the stem diameter at a given height or the stem height at a given diameter (Figure 2). For example, under conditions similar to the ones of the present study, a 30-meter high tree in the $23.0 \mathrm{~cm}$ DBH class has a diameter of approximately $8.0 \mathrm{~cm}$ at $25.0 \mathrm{~m}$ and of approximately $19.2 \mathrm{~cm}$ at $10 \mathrm{~m}$. 


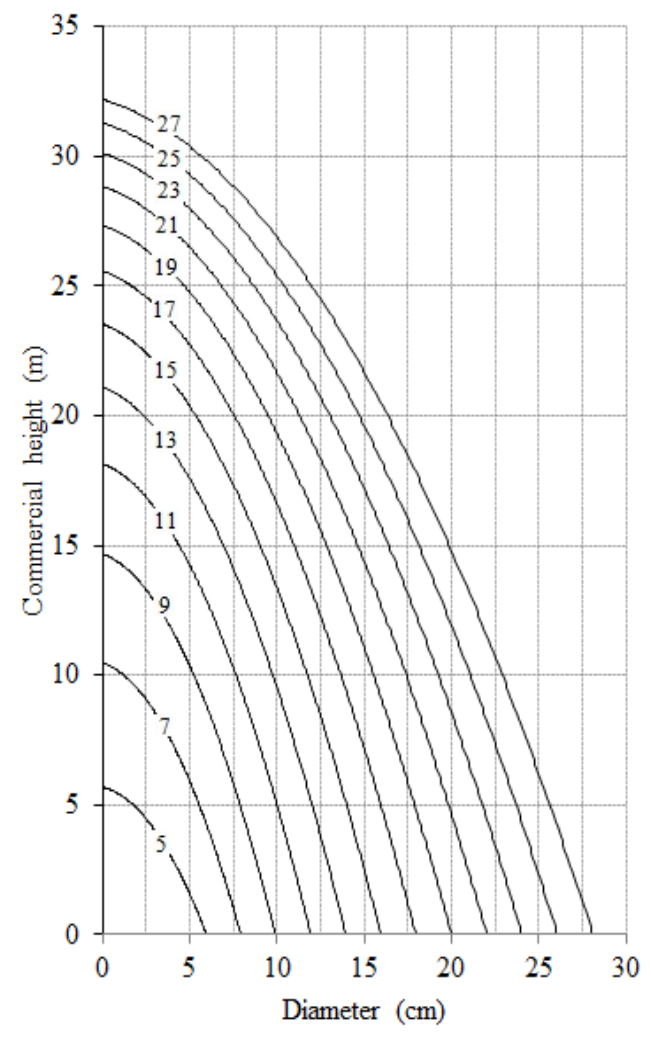

Figure 2. Graphical representation of stem profile of Eucalyptus urophylla $\mathrm{x}$ E. grandis hybrid estimated for DBH classes, with amplitude of $2.0 \mathrm{~cm}$ and ranging from 5.0 to $27.0 \mathrm{~cm}$, using the Demaerschalk model.

Figura 2. Representação gráfica do fuste da árvore do híbrido de Eucalyptus urophylla $x$ E. grandis estimado para classes de DAP com amplitude de 2,0 cm e variando de 5,0 a 27,0 cm, a partir do modelo de afilamento de Demaerschalk.

Due to the aforementioned characteristics - either those inherent to the model or those related to its accuracy with regards to the description of the stem tapering in this study -, the Demaerschalk model was chosen to be applied in a log cutting optimization system for obtaining multi-products.

In order to illustrate it, the optimized structure - i.e. the product that yields the maximum financial return using the tree wood with the minimum possible waste - is presented according to each diameter class. For trees in the $5.0 \mathrm{~cm}$ and $7.0 \mathrm{~cm}$ DBH classes, the wood obtained was entirely allocated for energy (firewood), since its dimensions were not sufficient for a more noble use. From $9.0 \mathrm{~cm}$ to $17.0 \mathrm{~cm}$ classes, the wood could be used for energy (firewood) and fence posts, and in the classes from $19.0 \mathrm{~cm}$ on, it could be used for all assortments. The largest volume and number of fence posts were obtained in the $17.0 \mathrm{~cm}$ class, whereas the largest volume and number of poles and the greatest volume of energy were found in the $19.0 \mathrm{~cm}$ class (Table 5). Considering all diameter classes, the largest volume of wood was allocated for fence posts, followed by poles and firewood.

Table 5. Optimized cutting structure for poles and fence posts - volume and number of units -, and wood volume for firewood of trees in the DBH classes from 5.0 to $27.0 \mathrm{~cm}$ in Eucalyptus urophylla x E. grandis hybrid stands.

Tabela 5. Estrutura ótima de corte em postes, mourões - volume e número de unidades - e volume de madeira para energia das árvores nas classes de DAP de 5,0 a $27,0 \mathrm{~cm}$ em povoamentos do híbrido de Eucalyptus urophylla $\mathrm{x}$ E. grandis.

\begin{tabular}{cccc}
\hline DBH class $(\mathbf{c m})$ & Assortment & $\mathbf{V}\left(\mathbf{m}^{\mathbf{3}} \cdot \mathbf{h a} \mathbf{-}^{\mathbf{1}}\right)$ & Quantity (Un.) \\
\hline 5.0 & Energy & 0.05 & - \\
\hline 7.0 & Energy & 0.34 & - \\
\hline \multirow{2}{*}{9.0} & Energy & 0.96 & - \\
& Fence post & 2.50 & 196 \\
\hline
\end{tabular}

FLORESTA, Curitiba, PR, v. 50, n. 3, p. 1439 - 1448, jul/set 2020.

Menezes, L.S. et.al.

ISSN eletrônico 1982-4688

DOI: $10.5380 /$ rf.v50 i3. 60513 


\begin{tabular}{cccc}
\hline \multirow{2}{*}{11.0} & Energy & 1.64 & - \\
& Fence post & 10.44 & 636 \\
\hline \multirow{2}{*}{13.0} & Energy & 3.07 & - \\
& Fence post & 22.35 & 1013 \\
\hline \multirow{2}{*}{15.0} & Energy & 2.23 & - \\
& Fence post & 41.49 & 1588 \\
\hline \multirow{2}{*}{17.0} & Energy & 3.03 & - \\
& Fence post & 72.49 & 2236 \\
\hline \multirow{2}{*}{19.0} & Energy & 3.39 & - \\
& Fence post & 37.61 & 1284 \\
& Pole & 45.00 & 214 \\
\hline \multirow{2}{*}{21.0} & Energy & 0.82 & - \\
& Fence post & 14.44 & 416 \\
& Pole & 15.31 & 59 \\
\hline \multirow{2}{*}{23.0} & Energy & 0.21 & - \\
& Fence post & 1.59 & 57 \\
& Pole & 7.34 & - \\
\hline \multirow{2}{*}{27.0} & Energy & 0.01 & 14 \\
& Fence post & 0.50 & 5 \\
\hline
\end{tabular}

The NPV varied $24.3 \%$ between the lowest and the highest interest rate studied. It could also be observed that the multi-product project is viable at any of the interest rates adopted (Table 6).

Table 6. Wood volume, revenue and costs corresponding to each assortment, and Net Present Value (NPV) at interest rates from 8.0 to $12.0 \%$ in a simulation of obtaining wood multi-products - poles, fence posts, and firewood - in a Eucalyptus urophylla x E. grandis stand.

Tabela 6. Volume de madeira, receitas e custos correspondentes a cada sortimento, e Valor Presente Líquido (VPL) a taxas de juros de 8,0 a 12,0 \% em simulação de obtenção de multiprodutos da madeira - postes, mourões e energia - em povoamento de Eucalyptus urophylla x E. grandis.

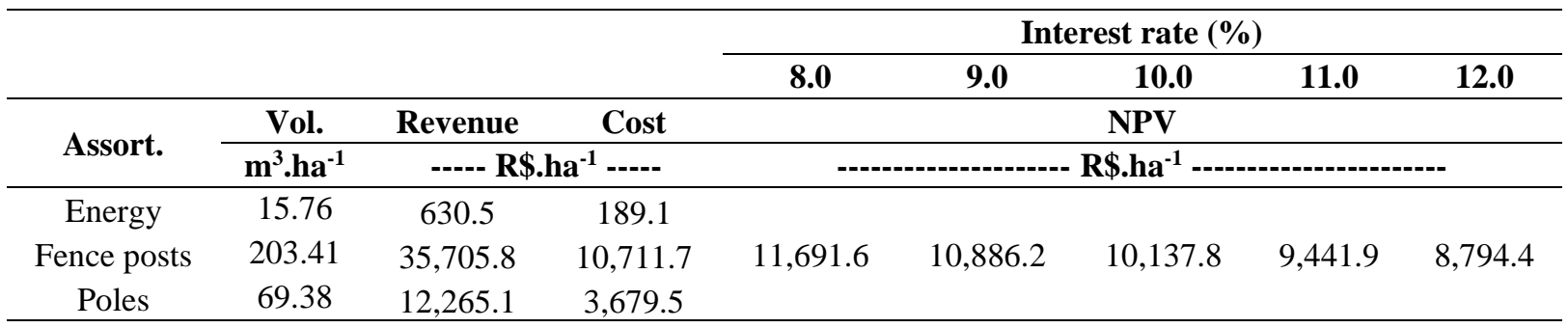

\section{DISCUSSION}

The Demaerschalk model demonstrated a better adjustment quality when compared to the other models tested. In addition to it, nonlinear models, such as Demaerschalk's, present as desirable advantages and characteristics: parsimony, interpretation of parameters and extrapolation. Therefore, they are more reliable when using other databases, in comparison to linear functions.

Among the simple models, Demaerschalk's is the most used one in Brazil. Studies by Leite et al. (2011), Silva et al. (2011), Muller et al. (2014), and Ribeiro and Andrade (2016) are examples of its application. Simple models are those in which a single function represents the entire shape of the stem, from its base to its top. They have the advantage of modeling the entire stem using only one expression, which confers them the flexibility to be adjusted and employed to produce multi-products (CAMPOS; LEITE, 2017).

The results found by Môra et al. (2014) and Campos et al. (2014) corroborate the present study regarding the adjustment quality of the Demaerschalk model. Both studies were conducted using data from stands of the

FLORESTA, Curitiba, PR, v. 50, n. 3, p. 1439 - 1448, jul/set 2020

Menezes, L.S. et.al.

ISSN eletrônico 1982-4688

DOI: $10.5380 /$ rf.v50 i3. 60513 
Eucalyptus urophylla x E. grandis hybrid in the state of Minas Gerais (Brazil). The first research was conducted in the municipality of São João Evangelista and the second one in the Zona da Mata region. Môra et al. (2014) found that, concerning the volume estimates, the Demaerschalk model (1972) presented the best distribution of residues in comparison to Kozak (1969) and Ormerod (1973) models. The values demonstrated no tendency for relative errors along the diameter classes. Campos et al. (2014) observed a high correlation between the estimated and observed diameter values, which consequently implies low and homoscedastic residual dispersion.

Once the Demaerschalk model was selected as the most appropriate for obtaining stem assortments from the stands analyzed in this study - and considering the existing demand for them -, the model was then used to optimize the stems into multi-products and for a further study of economic viability. The results of this study corroborate the ones observed by other researchers such as Soares et al. (2003) and Castro et al. (2011).

In an economic evaluation study for Eucalyptus grandis stands, Soares et al. (2003) observed that if the wood was entirely used for energy production, the project was unviable at the interest rate beginning at $6.0 \%$ p.a. They also noticed that, by converting wood into multi-products, the project becomes unviable only at the interest rate of $12.0 \%$ p.a. According to the authors, the sensitivity to the variations in the interest rate was expected since high discount rates tend to make long-term investments unviable. It occurs due to the long time of the investment conversion, as it is the case in the forestry sector.

Castro et al. (2011) found results indicating viability in all interest rates, which varied between 5.0 and $21.0 \%$, when studying the stem conversion into multi-products of a stand of the Eucalyptus urophylla $\mathrm{x}$ E. grandis hybrid, located in the Northeast region of the state of Bahia (Brazil), under different thinning regimes.

The increase in interest rates affects profit-making, thus risking the viability of forest enterprises. However, the present study indicates that the diversification of forest products, by seeking more noble uses for the largest possible volume of wood, can provide a great financial return to the forest producer. A similar result was observed by Soares et al. (2003a) in a study performed in the municipality of Sabinópolis (state of Minas Gerais, Brazil), which aimed at converting Eucalyptus grandis stands into multi-products - in that case, the alternatives were using wood for pulp, energy and sawmill. The authors observed the forest management allocated for multiproducts as being more profitable than that allocated for a single use.

When evaluating the economic viability of Eucalyptus dunnii stands in the South-Central region of the state of Paraná (Brazil), Vitale and Miranda (2010) obtained the NPV of R \$38,074.71/ha for wood multi-products. This value is higher than the results observed in the present study. The authors considered an interest rate of $6.75 \%$ p.a., and disregarded the harvesting costs, which are one of the most burdensome ones for forestry activities (MINETTE et al., 2008).

Even though wood from trees of short-rotation stands is not commonly converted into multi-products, it can be optimized according to the stem dimensions. It enables the forest producer to allocate larger amounts of wood for more noble uses, thus leading to higher revenues. Moreover, the economic viability evaluation by independent forest producers is essential for them to know the most profitable options for wood use. Thus, they can diversify their production and income, mainly in small and medium rural properties.

\section{CONCLUSIONS}

- The Demaerschalk model is the most appropriate one to study stem tapering and assortment determination in short-rotation stands of the Eucalyptus urophylla $\mathrm{x}$ E. grandis hybrid allocated for multi-products in the region where this study was conducted.

- The allocation of wood for multi-products - poles, fence posts, and energy (firewood) - is a viable option for stands of the Eucalyptus urophylla $\mathrm{x}$ E. grandis hybrid, according to the interest rates applied in the present study.

\section{REFERENCES}

CAMPOS, B. P. F.; BINOTI, D. H. B.; SILVA, M. L.; LEITE, H. G.; BINOTI, M. L. M. S. Efeito do modelo de afilamento utilizado sobre a conversão de fustes de árvores em multiprodutos. Scientia Forestalis, Piracicaba, v. 42, n. 104, p. 513 - 520, 2014.

CAMPOS, J. C. C.; LEITE, H. G. Mensuração florestal: perguntas e respostas. Viçosa: Ed. UFV, 5 ed. 2017, $636 \mathrm{p}$.

CASTRO, R. V. O.; LEITE, H. G.; NOGUEIRA, G. S.; SOARES, C. P. B.; ARAÚJO JÚNIOR, C. A.; CASTRO, A. F. N. M.; CRUZ, J. P.; SANTOS, F. L.; SOUZA, C. C. Avaliação econômica de um povoamento de eucalipto desbastado e destinado a multiprodutos da madeira. Scientia Forestalis, Piracicaba, v. 39, n. 91, p. 351 - 357 , 2011.

FLORESTA, Curitiba, PR, v. 50, n. 3, p. 1439 - 1448, jul/set 2020.

Menezes, L.S. et.al.

ISSN eletrônico 1982-4688 
DEMAERSCHALK, J. P. Integrated systems for the estimation of tree taper and volume. Canadian Journal Forest Research, Ottawa, v. 3, n. 1, p. 90 - 94, 1972.

HUSCH, B.; BEERS, T. W.; DUCEY, M. J.; KERSHAW JR, J. A. Forest mensuration. New Jersey: John Wiley \& Sons, 5 ed. 2017,632 p.

LANSSANOVA, L. R.; UBIALLI, J. A.; ARCE, J. E.; PELISSARI, A. L.; FAVALESSA, C. M. C.; DRESCHER, R. Avaliação de funções de afilamento para a estimativa de diâmetro de espécies florestais comerciais do bioma amazônico mato-grossense. Floresta, Curitiba, PR, v. 43, n. 2, p. 215 - 224, 2013.

KOZAK, A.; MUNRO, D. D.; SMITH, J. G. H. Taper functions and their applications in forest inventory. The Forest Chronicle, Mattawa, v. 45, n. 4, p. 278 - 283, 1969.

LEITE, H. G.; CAMPOS, J. C. C.; PAULA JR, G. G. P. Emprego de um modelo de programação dinâmica para conversão de troncos em multiprodutos da madeira. Árvore, Viçosa, v. 19, n. 4, p. 447 - 465, 1995.

LEITE, H. G.; OLIVEIRA-NETO, R. R.; MONTE, M.A.; FARDIN, L.; ALCÂNTARA, A. M.; BINOTI, M. L. M. S.; CASTRO, R. V. O. Modelo de afilamento de cerne de Tectona grandis L.f.. Scientia Forestalis, n. 39, v.89, p. $53-59,2011$.

MINETTE, L. J.; SILVA, E. N.; FREITAS, K. E.; SOUZA, A. P.; SILVA, E. P. Análise técnica e econômica da colheita florestal mecanizada em Niquelândia, Goiás. Revista Brasileira de Engenharia Agrícola e Ambiental, v.12, n.6, p.659-665, 2008.

MÔRA, R.; SILVA, G. F.; GONÇALVES, F. G.; SOARES, C. P. B.; CHICHORRO, J. F.; CURTO, R. A. Análise de diferentes formas de ajuste de funções de afilamento. Scientia Forestalis, Piracicaba, v. 42, n. 102, p. 237 249, 2014.

MÜLlER, M. D.; SAlleS, T. T.; PACIULlO, D. S. C.; BRIGHENTI, A. M.; CASTRO, C. R. T. Equações de altura, volume e afilamento para eucalipto e acácia estabelecidos em sistema silvipastoril. Floresta, Curitiba, PR, v. 44 , n. 3 , p. $473-484,2014$.

ORMEROD, D. W. A simple bole model. The Forest Chronicle, Mattawa, v. 49, n. 3, p. 136 - 138, 1973.

PRODAN, M. Holzmesslehre. Frankfurt am Main: Sauerlander’sVerlag, 1965.

REZENDE, J. L. P.; OLIVEIRA, A. D. Análise econômica e social de projetos florestais. Viçosa: Ed. UFV, 3 ed. 2013, 385 p.

RIBEIRO, J. R.; ANDRADE, V. C. L. Equações de perfil do tronco para Eucalyptus camaldulensis Dehnh no centro-sul tocantinense. Floresta e Ambiente, v. 23, n. 4, p. 534 - 543, 2016.

SILVA, F.; DALLA CORTE, A. P.; SANQUETTA, C. R. Equações de afilamento para descrever o volume total do fuste de Pinus caribaea var. hondurensis na região do Triângulo Mineiro. Scientia Forestalis, Piracicaba, v. 39, n. 91, p. 367 - 376, 2011.

SILVA, J. V.; NOGUEIRA, G. S.; SANTANA, R. C.; LEITE, H. G.; OLIVEIRA, M. L. R.; ALMADO, R. P. Produção e acúmulo de nutrientes em povoamento de eucalipto em consequência da intensidade do desbaste e da fertilização. Pesquisa Agropecuária Brasileira, Brasília, v. 4, n. 11, p. 1555 - 1562, 2012.

SILVA, M. L.; RESENDE, J. L. P.; LIMA JÚNIOR, V. B.; CORDEIRO, S. A.; COELHO JÚNIOR, L. M. Métodos do cálculo de custo da terra na atividade florestal. Cerne, Lavras, v. 14, n. 1, p. 75 - 81, 2008.

SOARES, T. S.; CARVALHO, R. M. M. A.; VALE, A. B. Avaliação econômica de um povoamento de Eucalyptus grandis destinado a multiprodutos. Árvore, Viçosa, v.27, n.5, p.689-694, 2003.

SOARES, T. S.; VALE, A. B.; LEITE, H. G.; MACHADO, C. C. Otimização de multiprodutos em povoamentos florestais. Árvore, Viçosa, v. 27, n. 6, p. 811 - 820, 2003a.

VITALE, V.; MIRANDA, G. M. Análise comparativa da viabilidade econômica de plantios de Pinus taeda e Eucalyptus dunnii na região Centro-Sul do Paraná. Floresta, Curitiba, v. 40, n. 3, p. 469 - 476, 2010.

YOSHITANI JR, M.; NAKAJIMA N. Y.; ARCE, J. E.; MACHADO, S. A.; DRUSZCZ, J. P.; HOSOKAWA, R. T.; MELLO, A. A. Funções de afilamento para plantios desbastados de Pinus taeda. Floresta, v. 42, n.1, p. 169 $176,2012$.

FLORESTA, Curitiba, PR, v. 50, n. 3, p. 1439 - 1448, jul/set 2020

Menezes, L.S. et.al.

ISSN eletrônico 1982-4688

1448

DOI: 10.5380/rf.v50 i3. 60513 